\title{
Temporal Sequencing Abilities in Musicians Violinists and Non-Musicians
}

\author{
Habilidades de Sequencialização Temporal em Músicos Violinistas e \\ Não-Músicos
}

\author{
Franklin Martins Nascimento*, Ricardo Alexandre Martinez Monteiro*, Carla Debus Soares**, \\ Maria Inês Dornelles da Costa Ferreira***.
}

\author{
* Bachelor in Speech Therapy. Speech therapist. \\ ** Masters. Professor of Speech Therapy Center Methodist University - IPA and Speech, Department of Audiology, Mother of God Center. \\ *** PhD. Professor of Speech Methodist University Center - IPA (Porto Alegre) and the School Our Lady of Fatima (Caxias do Sul). \\ Institution: Methodist University - IPA. \\ Porto Alegre / RS - Brazil. \\ Mail Address: Maria Inês Dornelles da Costa Ferreira - Rua Luiz Afonso 158/702 - Bairro: Cidade Baixa - Porto Alegre / RS - Brazil - Zip code: $90050-310$ - Telephone: \\ (+55 51) 9823-0198 - E-mail: costa.ferreira @ terra.com.br \\ Article received in March 5, 2010. Article accepted in April 23, 2010.
}

\section{SUMMARY}

Introduction:

Objective:

Method:

Results:

Conclusion:

Keywords:

\section{RESUMO}

Introdução:

Objetivo:

Método:

Resultados:

Conclusão:

Palavras-chave:
The ability of temporal sequencing refers to the processing of two or more auditory stimuli in order of occurrence in time.

To compare the skill of sequencing between musicians and non-musicians violinists from the frequency pattern test (FPT).

The prospective, constituted a group of 20 violinists and musicians non-musicians 20 participants, half matched for age and education, all males who underwent audiometric assessment and WPPT.

Comparing the performance in TFP between the groups was found statistically significant for the group of musicians in both ears, $(p=0.003)$ for the right ear (RE) and $(p=0.002)$ for the left ear $(\mathrm{OE})$. The results of the PPT were correlated with the average frequencies, three-tone average and high frequencies mean obtaining a statistically significant only for OD being $(p=0.0047)$ for low frequencies, $(p=0.011)$ for average and tritonal ( $p=0.02)$ for the average frequencies. The comparative analysis between the ears, the only group statistically significant variable was the mean of frequencies in the group of musicians $(\mathrm{p}<0.001)$.

The performance of the group of musicians in the TPF group was superior to non-musicians. Highlights the relevance of the auditory thresholds for low frequencies, acute tritonal average performance of TPF in OD.

music, auditory threshold, hearing tests, auditory perception.

A habilidade de sequencialização temporal, refere-se ao processamento de dois ou mais estímulos auditivos na ordem de ocorrência no tempo.

Comparar a habilidade de sequencialização entre músicos violinistas e não-músicos a partir do teste de padrão de frequência (TPF).

O estudo, prospectivo, constituiu-se num grupo de 20 músicos violinistas e 20 participantes não músicos, semi pareados por idade e escolaridade, todos do gênero masculino que foram submetidos à avaliação audiológica básica e TPF.

Ao comparar o desempenho no TPF entre os grupos verificou-se relação estatisticamente significativa para o grupo de músicos em ambas as orelhas; $(\mathrm{p}=0,003)$ para a orelha direita $(O D)$ e $(\mathrm{p}=0,002)$ para a orelha esquerda (OE). Os resultados do TPF foram correlacionados com a média das frequências graves, média tritonal e média das frequências agudas obtendo relação estatisticamente significativa apenas para OD sendo $(\mathrm{p}=0,0047)$ para as frequências graves, $(\mathrm{p}=0,011)$ para a média tritonal e $(\mathrm{p}=$ $0,02)$ para a média das frequências agudas. Na análise comparativa entre as orelhas, por grupo a única variável estatisticamente significativa foi a média das frequências graves no grupo de músicos $(\mathrm{p}<0,001)$. O desempenho do grupo de músicos no TPF foi superior ao grupo de não músicos. Destaca-se a relevância dos limiares auditivos para as frequências graves, agudas e média tritonal no desempenho do TPF na OD.

música, limiar auditivo, testes auditivos, percepção auditiva. 


\section{INTRODUCTION}

The auditory processing (central) (PA (C)) refers to the efficiency and effectiveness with which the central nervous system (CNS) utilizes auditory information. Involves the mechanisms and processes responsible for the auditory system: sound localization and lateralization, auditory discrimination and recognition of patterns and temporal aspects of hearing (1).

Already temporal auditory processing (TAP) can be defined as the perception of sound or change the sound within a restricted domain of time or set to be a key component of a greater capacity for auditory processing. This is strongly supported by the fact that many features of auditory information are somehow under the influence of time, being subdivided into areas of study such as resolution, masking, integration and temporal ordering. Among those present study will address the temporal ordering (2).

The coding of sensory information such as temporal duration, interval and order of different stimulus patterns provides information vital to the nervous system. All these clues, which govern the temporal processing are important for speech perception and music, since structure of these two events presented as rapid changes of the acoustic signal. In tests that delineate the temporal summation or integration the subject must detect weak signals in background noise or silence. The temporal masking is characterized by changing the threshold of a sound in the presence of another stimulus thereafter. This occurs when a stimulus is presented with sufficient intensity and duration to reduce the sensitivity of another stimulus presented before or after the initial stimulus (3).

The temporal resolution or discrimination refers to the shorter duration of time in which an individual can discriminate between two auditory signals. The threshold of temporal resolution is known as auditory acuity or temporal integration time limit (2).

A temporal ordering or sequencing refers to the processing of two or more auditory stimuli in order of their occurrence in time. This was a phenomenon highly investigated, particularly because of its importance in speech perception. This process is not restricted to one hemisphere only, but requires integration of information from both hemispheres through the corpus callosum. The frequency pattern test (TPF) aims to investigate the temporal ordering before three stimuli that differ in frequency, contributing to the investigation of possible changes in PAT (4).
Many evidences suggest that the skills of the PAT are reflected in basic auditory processing, specifically in regard to speech perception, since the characteristics of auditory information influenced by time, reaching the auditory system of joint and successive manner $(5,6)$.

We know, too, that the auditory memory is a process that allows you to store and archive auditory information retrieving them later. This memory is essential for the auditory processing might behave in the full exercise of their capabilities. Thus, the ability of temporal ordering of sound stimuli is one of the most basic and important functions of the central auditory nervous system (7).

A study compared a group of musicians and nonmusicians in different auditory temporal tasks and found that the performance of the musicians' performance was superior to non-musicians (8).

A study of temporal ordering between professional and amateur singers tuned and untuned showed the superiority of TPF musicians who have received appropriate music theory over the years before those who did not receive any kind of theoretical orientation of music, making it clear that the exposure time Music theory is an important factor in the PAT (9).

Another study was conducted to TPF and duration pattern test (DPT) in musicians and nonmusicians. The results showed better performance when compared to TPD TPF, but the study had a small sample is necessary to sample a more significant for confirmation of results (10).

The aim of this study is to compare the abilities of sequencing between musicians and nonmusicians violinists from the TPF and the comparison of audiometric thresholds between the ears of the group of musicians.

\section{METHOD}

The study was conducted in the audiology laboratory of the institution where the study was conducted, and was approved by the Research Ethics Committee, under protocol 123/2008, characterized for being a prospective, cross-sectional, individual, observational contemporary and comparative.

After clarification aims of the research participants signed the Informed Consent (IC) and the responsible institution of which belonged to the study group signed the Statement of Institutional authorization (TAI). 
The criteria for including participants in the study, subjects were musicians violinists Christian Congregation of Brazil (CCB) formed the study group. These musicians did not perform any other musical activity outside the standards of the orchestra of the CCB. The main standardization of the orchestra of CCB is to expose the musicians to a standard of 450 hymns via orchestrated musical score. The same prior to constitute themselves as musicians in the orchestra performed an official musical training at the institution in which they initially prioritizes music theory and after passing through internal assessment begins contact with the instrument. The musicians participating in this study were already at the level of implementation of hymns after passing through the early processes of learning.

For the control group participants included nonmusicians paired with the study group according to age and the educational level, subdivided into elementary school, complete primary education, incomplete secondary education, secondary education, higher education incomplete and complete higher education. The exclusion criteria were established to present those changes in auditory thresholds.

Exclusion criteria for both groups stand out individuals who refused to participate in the survey, those who were representative of changes in tympanometry middle ear, as well as users of psychotropic medication or neurological. These criteria were obtained through a specific questionnaire for musicians and nonmusicians and by measuring the acoustic impedance.

It is worth mentioning that the alterations in tone audiometry shaped exclusion criterion for the group of musicians and non-variable to be analyzed for the group of musicians. The collection was made in the morning to ensure the hearing rest of the group of musicians.

After fit on the criteria for inclusion all participants underwent inspection of the external auditory canal to check the conditions of the examinations thereafter. Thus, participants were 20 male violinists musicians and 20 nonmusicians semi-individuals matched by age and educational level.

Measures of acoustic impedance were performed with the equipment AT22t brand Interacoustics and consisted of tympanometry and acoustic reflexes in both ears.

Pure tone audiometry was the second review conducted by the equipment AC30 and AC33 both brand Interacoustics.
All equipment found to be calibrated on the date on which the assessments were performed.

The third and final test used was the WPPT, accomplished by connecting the audiometer AC30 or AC33 CD player with Philips brand model AX2420/78. The test is the identification of three tones that differ in two frequencies: $1430 \mathrm{~Hz}$ (high) and $880 \mathrm{~Hz}$ (low) Each tone lasts $500 \mathrm{~ms}$, with a difference of $10 \mathrm{~ms}$. The interval between the three tones is $300 \mathrm{~ms}$ and the interval between each tone sequence is $10 \mathrm{sec}$. The tones are combined in six different patterns of frequency: high-high-low, high-low-low, high-low-high, low-highhigh, low-high-low and low-low-high and sound stimuli were presented at an intensity of above average 50dBNS tritonal researched the individual that reproduced the sequence heard murmuring sounds presented monaurally (11).

To describe the sample profile according to the variables under study were frequency tables of categorical variables, with values of absolute frequency (n) and percentage (\%), and descriptive statistics of continuous variables with the mean values, standard deviation values minimum and maximum, and median.

For comparison of categorical variables between groups was used Fisher's exact test. To compare numerical variables between two groups we used the Mann-Whitney, and to compare numerical variables between three or more groups, we used the KruskalWallis.

To compare numerical variables between the right ear (RE) and left ear (LE) was made using the Wilcoxon test for related samples.

To examine the relationship between numerical variables we used the Spearman correlation coefficient.

The level of significance for statistical tests was 5\%.

\section{RESULTS}

The present study constitutes a group of 20 musicians and 20 violinists participating non-musicians semi-matched age and education, all male.

For age 10 participated in the study (50\%) musicians under the age of 20 years, 3 (15\%) aged between 20 and 29 years of age and seven (35\%) aged greater than or equal to 30 years.

In the control group nine (45\%) participants 


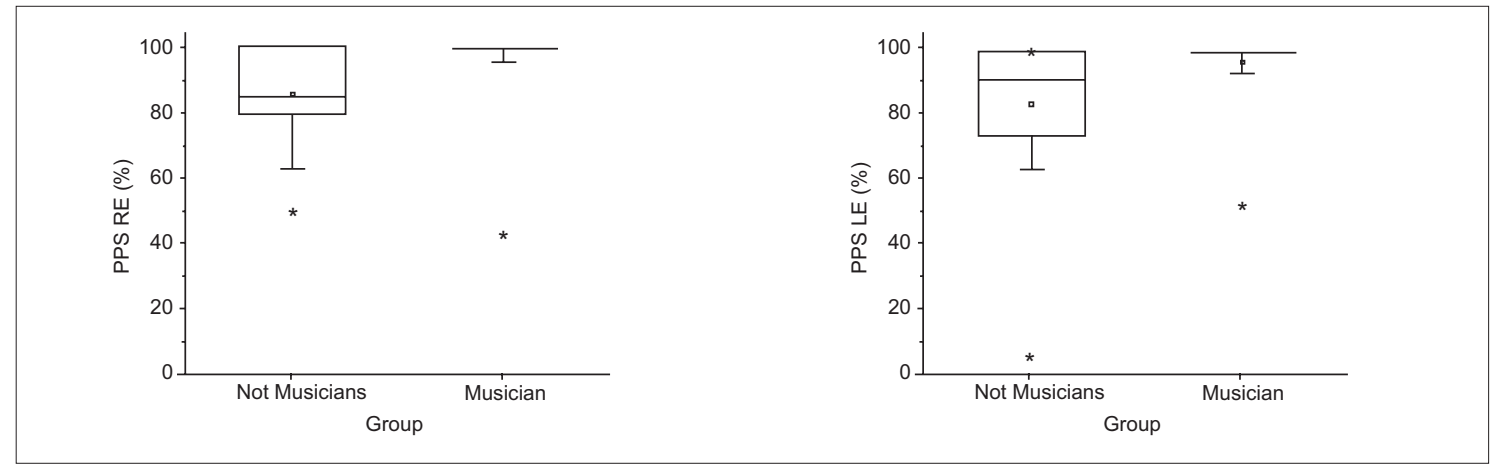

Figure 1. Performance of TPF for RE and LE when comparing the groups - RE: right ear, LE: left ear, PPS: Pitch Pattern Sequence (Pattern Test Frequency TPF).

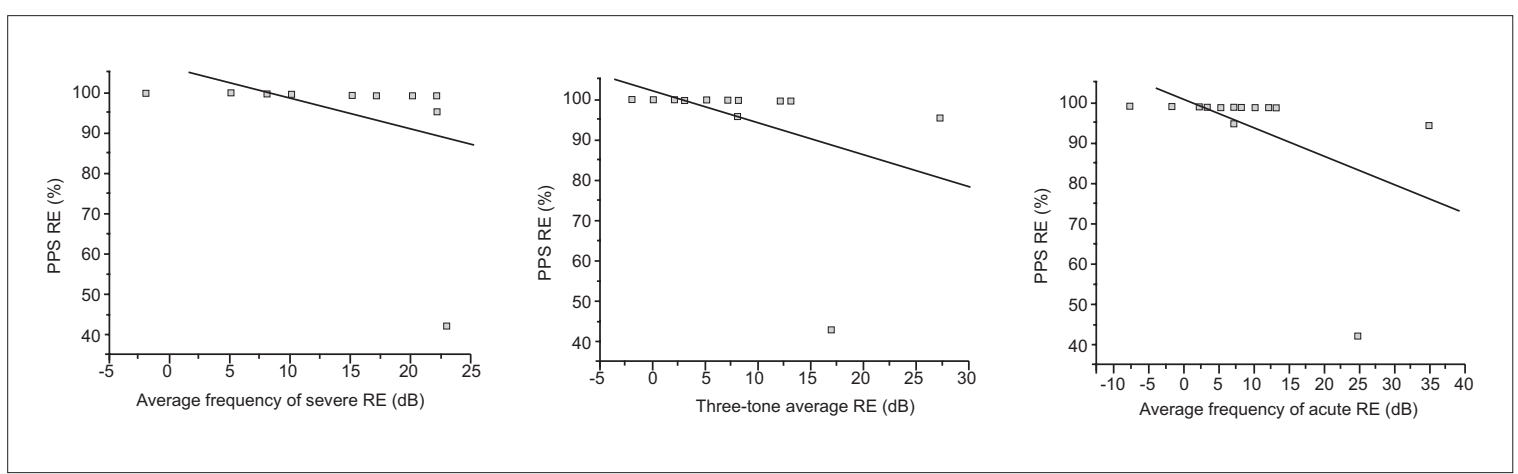

Figure 2. Correlation of TPF with the average frequency of severe, acute, three-tone average for the RE. RE: right ear PPS: Pitch Pattern Sequence (Pattern Test Frequency TPF).

were younger than 20 years, four (20\%) aged between 20 and 29 years of age and seven (35\%) aged less than 30 years.

The group of three musicians (15\%) had incomplete primary education, 6 (30\%) had incomplete secondary education, 7 (35\%), secondary education, 2 (10\%), higher education and two incomplete (10\%) had a university degree. In the control group, in turn $5(25 \%)$ of participants attended the elementary school; $3(15 \%)$ had incomplete secondary education, 7 (35\%), secondary education $2(10 \%)$, higher education is incomplete and 3 (15\%) had a university degree.

Figure 1 shows the performance of the PPT for both ears in the comparison between the groups in which there is statistically significant for RE $(p=0.003)$ and for OS $(p=0.002)$ in the group of musicians.

Following the analysis between the results of the
PPT were compared variables age and education level in each group showing no statistically significant relationship.

Correlation analysis of the results obtained in the FPT with the variables age, average of low frequencies, three-tone average and average high frequencies per ear were performed using the Spearman correlation test considering the groups separately.

Figure 2 shows the results obtained in the WPPT $\mathrm{OD}$ when correlated to the variables mean frequencies $(\mathrm{r}=-0.604, \mathrm{p}=0.0047)$, mean tritonal $(\mathrm{R}=-0.553, \mathrm{p}=$ $0.011)$ and mean high frequencies $(\mathrm{R}=-0.499, \mathrm{p}=0.02)$ in the same ear. The results indicate that the lower values of the mean frequencies, sharp and three-tone average, higher values of the WPPT.

The same result was not observed for the correlation of the PPT performed in the LE for the same 
variables allowing for the fact that the audiometric threshold at OD interfere with the performance of TPF to the ipsilateral ear.

Finally, the comparative analysis between the OD and OS was performed by the group. The only statistically significant variable was the mean of low frequencies when comparing both ears in the group of musicians, and the OD values were higher $(\mathrm{p}<0.001)$. With this result it is clear that the group of musicians has audiometric thresholds at OD worse than the contralateral ear for the bass frequencies.

\section{DISCUSSION}

The initiative of this study is due to the first author's experience as a performer violinist by questions related to hearing and the PAT.

The result shown in Figure 1 indicates that the musicians scored better than violinists TPF compared with non-musicians. The musical training provides greater insight into the discrimination of frequency since the musical practice provides this ability.

During the FPT observed in the group of musicians that came the murmur of the very tone of the sound stimulus by performing the repetition of the sound very precisely. This finding was seen in more experienced players with longer music theory (9).

Another point to note is that the capability of temporal orientation assessed in TFP is considered as a basic ability of the central auditory system (7).

Thus the results of this study confirms other studies with similar designs in which the performance of the group of musicians was higher than among nonmusicians $(8,9,10,12)$.

Studies involving neuroimaging musicians found greater activation in the temporal region in relation to non-musicians because the use of specialized regions in the short-term memory (13).

Moreover, the music considered external environmental factor may contribute to neural plasticity by increasing the skills of pattern recognition frequency (14).

Compared to the same result, another important consideration is related to socio language because, in Brazil, children are not exposed to formal musical training, unlike North American children (12).
This lack of exposure to music at an earlier stage might have contributed to the results for the group of non-musicians.

The results presented in Figure 2 show that the smaller group of musicians as the averages of these frequencies, sharp and three-tone average of the right ear, the higher the values of the WPPT.

This study differs from results reported by CoRAzzA (15) in their findings that found no statistically significant differences between right and left ears in the WPPT, may miss by not being musicians or even by being a homogenized population comprised a population of 80 adults young people who had no hearing loss.

Another study found a significant difference between right and left eyes left in a population of 211 Brazilian children, but only in verbal response, the murmur in this study showed no significant difference, the study suggests that Brazilian children because they are more accustomed to verbalize sounds of murmuring that they played a better result in verbal responses (16).

This result underscores the importance of the integrity of the thresholds for the discrimination of tonal frequencies. Already PDT not rely solely on the frequency discrimination, seems more resistant to peripheral hearing loss, because cochlear lesions interfere with the identification of frequencies due to its tonotopic organization (2).

Another aspect to be emphasized is the difference between the ears, the result was statistically significant for RE only for the group of musicians. Thus, studies with children and young adult non-musicians did not find significant differences between the ears to consider the FPT in murmuring condition $(15,16)$.

The ability to recognize, identify, and the pattern sequencer often involves many perceptual and cognitive processes that involve the integration of both hemispheres, the left hemisphere is responsible for the temporal sequencing and the recognition of the right boundary acoustic (17)

Thus, we hypothesized that the statistical significance for the OD group of musicians should be the position of the violin on the left side which sound travels through nonverbal generated two thirds of the auditory pathway that side to be recognized by the right hemisphere.

Finally, Figure 3 shows the comparison of average frequencies between the ears in the group of 
musicians, pointing out that the thresholds of the OD of the group are worse when compared to the thresholds of the OE.

When considering the position of orchestra musicians in the OD is exposed to other violins and other instruments, a high sound pressure level which could contribute to raising the ceiling.

A study of 30 musicians who were exposed to sound pressure levels exceeding 85 SPL identified changes in auditory thresholds in both the ears (18).

By contrast other studies focused on workers exposed to occupational noise thresholds in the RE found worse for no apparent reason (19).

One study showed a greater hearing loss in the left ear of the population studied, consisting of musicians from the symphony orchestra of Minas Gerais, with a greater loss in high frequencies and not the average frequencies as the findings of this study (20).

It should emphasize the physical aspects of the violin, whose sound is clear from the waveform generated by the excitation of the strings by the arc modulated by the vibrations and resonances of the violin body, their heads and bridge are the two main resonances generated by this complex instrument, observed between $3000 \mathrm{~Hz}$ and $6000 \mathrm{~Hz}$

The vibration generated is asymmetric depending on the soul of the violin, which is a kind of stick placed between the top head and lower part that generates the sound propagation, it makes only omnidirectional sound radiation frequencies between $200-500 \mathrm{~Hz}$ have between 350 and $1000 \mathrm{~Hz}$ it becomes partially omnidirectional and between $1000-5000 \mathrm{~Hz}$ is very directional, which can provide a risk of developing NIHL due to exposure directed at high frequency and high intensity. Thus, studies show that one listener 3 meters of the instrument perceives a sound intensity level of about $76 \mathrm{~dB}$ when playing high E string of the violin, practice this, unusual for musicians (21).

The elevation of hearing thresholds greater in the OD group of musicians can also be explained by accompanying other instruments. The sound pressure level increased more with the violin near the ear, because the play, the musicians violinists tilt the head to the left side and rotate down to accommodate the instrument by increasing the exposure of the OD to the sound that comes from omnidirectional full orchestra.

According to the findings, the musical practice

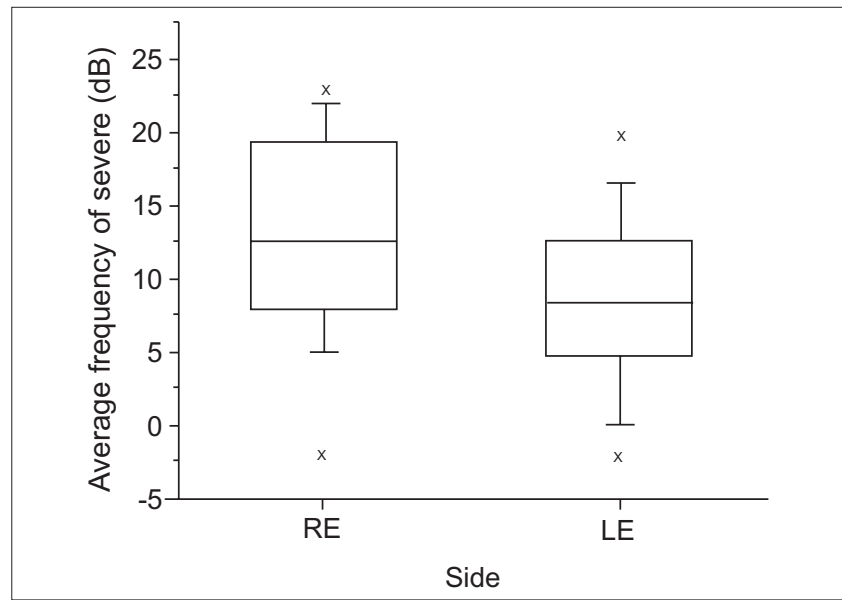

Figure 3. Comparative analysis of the average frequencies for right and left ears in the group of musicians. - RE: right ear: LE: left ear.

may be regarded as a form of auditory training for individuals with the PAT to increase synaptic activity through behavioral changes (22).

In addition, music was considered a pleasurable activity capable of expressing feelings (9), can motivate patients in the rehabilitation process.

\section{CONCLUSION}

The aim of this study was to compare the ability of temporal sequencing between musicians and nonmusicians violinists from the TPF.

The performance of the musicians in the TPF group was statistically significant, demonstrating better performance compared to the control group, allowing the identification of the relevance of the auditory thresholds for low frequencies, sharp and three-tone average in that test in the OD.

It was also possible to see the difference between the average thresholds of low frequencies between the ears in the group of musicians.

\section{Biblographic ReFERENCE}

1. ASHA: American Speech-Language-Hearing Association. (Central) Auditory Processing Disorders [Technical Report], 2005 Disponível em: www.asha.org/ policy.

2. Shinn JB. Temporal processing and temporal patterning 
tests. In: Musiek FE, Charmak GD. Handbook of (central) auditory processing disorders: auditory neuroscience and diagnosis. San Diego: Plural Publishing; 2007, Vol. 1, pp 231-243.

3. Samelli AG, Schochat E. Processamento auditivo resolução temporal e teste de detecção de Gap: revisão de literatura. CEFAC. 2008, 10(3):369-377.

4. Balen SA, Massignani R, Schillo R. Aplicabilidade do software fast forword na reabilitação dos distúrbios do processamento auditivo: resultados iniciais. CEFAC. 2008, 10(4):572-587.

5. Shibata T, Sakashita T, Yamane H, Hashimoto C.Temporal resolution and speech recognition ability of patients with retrocochlear auditory dysfunction. Acta Otolaryngol Suppl. 2004, 124(554):30-34.

6. Phillips DP. Neural representation of stimulus times in the primary auditory cortex. Ann N Y Acad Sci. 1993, 682(1):104-18.

7. Miranda ES, Pereira LD, Bommarito S, Silva TM. Avaliação do processamento auditivo de sons não-verbais em indivíduos com doença de Parkinson. Rev Bras Otorrinolaringol. 2004, 70(4):534-539.

8. Rammsayer T, Altenmüller E. Temporal information processing in musicians and non-musicians. Music Perception. 2006, 24(1):37-48.

9. Ishll C, Arashiro PM, Pereira LD. Ordenação e resolução temporal em cantores profissionais e amadores afinados e desafinados. Pró-Fono. 2006, 18(3):285-292.

10. Taborda MBL. Processos Temporais Auditivos em Músicos de Petrópolis. Rio de Janeiro, 1999, p.76, (Monografia de Especialização) - Universidade Federal de São Paulo e Universidade Católica de Petrópolis.

11. Auditec, Evaluation Manual of Pitch Pattern Sequence and duration Pattern Sequence. Missouri, USA, 1997.

12. Peroni CP. Analise da influencia da modalidade de resposta não-verbal, que melhor se adapta ao teste de padrão de freqüência, em um grupo de brasileiros nativos.
São Paulo, 2005, p. 75, (Dissertação de Mestrado) Pontifícia Universidade Católica de São Paulo - PUC-SP.

13. Gaab N, Schlaug G. The effect of musicianship on pitch memory in performance matched groups. Neuroreport. 2003, 14(18):2291-5.

14. Zalcman TE, Schochat E. A eficácia do treinamento auditivo formal em indivíduos com transtorno de processamento auditivo. Rev Soc Bras Fonoaudiol. 2007, 12(4):310-4.

15. Corazza MCA. Avaliação do processamento auditivo central em adultos: testes de padrões tonais auditivos de freqüência e teste de padrões tonais auditivos de duração. São Paulo, 1998, p. 150, (Tese de Doutorado) Universidade Federal de São Paulo.

16. Balen AS. Desenvolvimento das habilidades de reconhecimento de padrões auditivos temporais em crianças de 7 a 12 anos. São Paulo, 2001 (Tese de Doutorado) - Universidade de São Paulo.

17. Shinn JB. Temporal processing: the basics. Hear J. 2003, 56(7):52.

18. Amorim RB, Lopes AC, Santos KTP, Melo ADP, Lauris JRP. Alterações Auditivas da Exposição Ocupacional em Músicos. Arq. Int. Otorrinolaringol. 2008, 12(3):377-383.

19. Santos JD, Costa-Ferreira MID. Variação dos limiares audiométricos em trabalhadores submetidos a Ruído ocupacional, Arq. Int. Otorrinolaringol. 2008, 12(2):201209.

20. Maia AA, Gonçalves DU, Menezes LN, Barbosa BM, Almeida PS, Resende LM. Análise do perfil audiológico dos músicos da orquestra sinfônica de Minas Gerais (OSMG). Per Musi. 2007, 15:67-71.

21. Donoso JP, Tannús A, Guimarães F, Freitas TC. A física do violino. Rev Bras Ensino de Fís. 2008, 30(2):2305-21.

22. Kozlowski L, Wiemes GMR, Magni C, Silva ALG. A efetividade do treinamento auditivo na desordem do processamento auditivo central: estudo de caso. Rev Bras Otorrinolaringol. 2004, 70(3):427-32. 
Version in Portuguese uses is page. 